\title{
Functional Independence of Adults and the Elderly Attended by a Family Health Strategy in Teixeira de Freitas-BA
}

\section{Independência Funcional de Adultos e Idosos Atendidos por uma Estratégia de Saúde da Família em Teixeira de Freitas-BA}

\author{
Marina Lima de Oliveira Carvalho; ; Gabriel Almeida Santosª Murilo Sousa Ramos ${ }^{\mathrm{a}}$; Grasiely Faccin Borges*ab
}

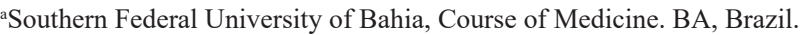

\author{
${ }^{b}$ Research Center of Sport and Physical Activity of the University of Coimbra-Portugal. Portugal. \\ *E-mail: grasiely.borges@gmail.com \\ Recebido em: 23/05/2019; Aprovado em: 22/10/2019
}

\begin{abstract}
Aging is related to several morphological and functional changes in the individuals' body that directly reflects on their functional independence. This affects both maintaining the ability to perform Basic Activities of Daily Living and the Instrumental Activities of Daily Living. The present study aimed to verify the level of functional independence in adults and the elderly attended by a Family Health Strategy in Teixeira de Freitas-BA. It is an observational study of transverse and descriptive design composed of 30 participants who answered a semi-structured questionnaire and socioeconomic Functional Independence Measure instrument (MIF). Spearman's correlation coefficient was used to analyze the correlation among the variables. Through MIF it was possible to identify a total of $123.1 \pm 4.47$ points for the participants, which indicates complete independence in performing routine tasks. The memory factor was the component that scored lower, followed by problem resolution. A strong correlation $(r=0.71)$ was found between the total MIF score and the social cognition factor. Therefore, one notices the need for investments in appropriate professionals as well as improvement in public health policies in order to active and healthy aging.
\end{abstract}

Keywords: Health Care (Public Health). Aged. Activities of Daily Living.

\section{Resumo}

O envelhecimento está relacionado à diversas alterações morfológicas e funcionais no organismo dos indivíduos que reflete diretamente na independência funcional destes. Isso afeta tanto na manutenção da habilidade de realizar Atividades Básicas da Vida Diária quanto nas Atividades Instrumentais da Vida Diária. O presente estudo teve por objetivo verificar o nível de independência funcional em adultos e idosos atendidos por uma Estratégia Saúde da Família em Teixeira de Freitas-BA. É um estudo observacional de delineamento transversal e descritivo, foi composto por 30 participantes que responderam a um questionário socioeconômico semiestruturado e o instrumento de Medida de Independência Funcional (MIF). Para as análises foi utilizado o coeficiente de correlação de Spearman para avaliar a correlação existente entre as variáveis. Por meio da MIF foi possivel identificar um total de 123,1土4,47 pontos para os participantes, o que indica a independência completa na realização de tarefas de rotina. O fator memória foi o componente que obteve menor pontuação, seguido de resolução de problemas. Constatou-se nesse estudo uma correlação forte $(r=0,71)$ entre a pontuação total da MIF e o fator cognição social. Assim, percebe-se a necessidade de investimentos em profissionais adequados bem como melhoria nas políticas públicas de saúde a fim de promover um envelhecimento ativo e saudável.

Palavras-chave: Atenção à Saúde. Idoso. Atividades Cotidianas.

\section{Introduction}

The Pan-American Health Organization - PAHO, together with the World Health Organization (WHO) ${ }^{1}$ pointed out in 2016, the number of persons aged greater than or equal to 60 years will more than double, from 900 million to around 2 billion worldwide in 2050 . This rapid population aging may increase the occurrence of non-transmissible chronic diseases that are directly related to an increased risk of disability and mortality, in addition to the impairment of quality of life $\mathrm{e}^{2.3}$.

The functional disability is understood as a multidimensional condition, a result of the relationship between the individual and his or her physical/social environment. The inability or difficulty performing activities range from basic activities to the most complex, directed to their everyday life 2.4 .

The National Health Policy of the Elderly in Brazil brings a model for promoting and maintaining the autonomy and independence of the elderly, with emphasis on functional capacity $^{5}$. This policy aims to prioritize the preservation, improvement and rehabilitation of the functional capacity of the elderly, to ensure their participation in society, exercising their daily activities independently ${ }^{6}$.

Therefore, it is important to highlight the maintenance of the ability to perform basic Activities of Daily Living (ABVD) and instrumental activities of daily living (AIVD), as essential and acceptable for an independent and autonomous life. The achievement of the ABVD and the AIVD for the elderly, is something present and necessary for their survival, keeping the participatory approach in managing and caring for their 
own health and the development of domestic tasks ${ }^{7.8}$.

The search for an active aging, with quality of life is being objective of social programs and health care, directed toward the preservation of independence and autonomy. This investment has not been fundamental goal only from the government, but of all sectors of society. Thus, as an important strategy for achieving this challenge, the program Family Health Strategy stands out, developed in Family Health Units, being registered as competent to achieve specific measures of health prevention and promotion, especially taking care with the elderly living in the community ${ }^{6.7}$.

The elderly who maintains their independence and the ability to exercise their autonomy, must be considered healthy even if the same is diagnosed with one or more chronic diseases ${ }^{9}$. From a public health point of view, the functional capacity shows itself as an integral part of the concept of health conducive to implement and operate a policy of attention to the health of the elderly ${ }^{10}$.

The functional independence has been used in different scenarios of attention to elderly health both in Brazil and in other countries. An instrument to assess the individuals' cognitive and motor ability is the Measure of Functional Independence-MIF file that has had good acceptance in the scientific community, because in addition to allowing the measurement of the degree of the elderly dependence, can also quantify the demand for care that they may present ${ }^{11}$.

Cognitive deficits, for example, have been associated with functional loss ${ }^{12}$ and furthermore, changes in memory, executive function and attention are related to low gait and may predict loss of mobility, falls and progression of cognitive decline ${ }^{13}$. On the other hand, elderly practitioners of regular physical activity may present better results or maintain the cognitive status, functional capacity and ability to perform activities of daily living, compared to the non-active elderly ${ }^{14}$.

In this perspective, the objective of this study is to verify the level of functional independence, compare by gender and age the level of functional independence and identify which areas and factors of the measure of functional independence would be more compromised in the elderly cared for by a Family Health Strategy (FHS) in Teixeira de Freitas-Bahia. Considering the above, the results can contribute to the survey of the elderly population needs in relation to their inability and also provide data on the functional disability.

\section{Material and Methods}

It is a sectional observational and descriptive study. The study sample consisted of 30 participants of both sexes, assisted by a FHS, located in the municipality of Teixeira de Freitas/Bahia. After being informed about the benefits and risks of the research, they agreed to sign the Informed Consent Form(TCLE) (CEP of UEFS, CAAE: 58368216.1.0000.0053) participating in the study voluntarily.

The participants answered a structured questionnaire containing 30 sociodemographic questions, about health and the instrument Measure of Functional Independence MIF. The instrument has the function to assess quantitatively the load of cares needed for a person to perform motor and routine cognitive activities. On a scale of 7 points 18 items are evaluated that include the individual's personal care, control of sphincters, motility, locomotion, communication and social $\operatorname{cognition}^{15}$.

The total score of MIF is obtained by summing the score of each dimension, having as a minimum 18 and maximum 126 points. A result of 18 points, it is considered that there is dependence, complete with need of total assistance to perform daily tasks; 19 to 60 points, modified dependence, with the assistance of up to $50 \%$ on the job; from 61 to 103 points, modified dependence, with the need for assistance of up to $25 \%$ on the task and 104 to 126 points, equivalent to complete independence/modified ${ }^{16}$.

This tool was chosen for being a measure which meets the criteria of reliability, validity, accuracy, convenience and ease. In addition, it is part of a uniform system for Medical Rehabilitation, being widely used and accepted as a measure of functional evaluation internationally. It also 1 has as a goal to determine what the necessary cares to be offered so that the patient performs the ABVD and AIVD. Afterwards, the collected data were tabulated and archived in the electronic database available in spreadsheets.

To evaluate the correlation between two variables Spearman's correlation coefficient was used. The degree of linear relationship between two quantitative variables varies between -1 and 1 . About the result of the correlation, the value 0 (zero) means that there is no linear relationship, the value 1 indicates a perfect linear relationship, and the value -1 also indicates a perfect linear relationship, but in reverse. The qualitative assessment of the degree of correlation between two variables can also be called as null, if a correlation coefficient $(r)=0$ is obtained. I case it is obtained a $r>0$ and $<0.3$ it would be weak, for $r \geq 0.3$ and $<0.6$ it is known as regular correlation, the correlation can still be called strong, very strong and full, if the $r$ obtained is respectively between: $\geq 0.6$ and $<0.9, \geq 0.9$ and $<1$ and $=1^{17}$. For the Spearman correlation, performed in the study variables, it was used the program SAS 9.0.

A comparison analysis was also made taking into consideration the age to identify the involvement in motor and cognitive domains. For this reason, the WHO criterion was used, which classifies older adults aged over 60 years. Thus, the studied group was divided in $<60$ years and $>60$ years.

\section{Results and Discussion}

The studied sample consisted of 30 participants. The mean age of the group was $63.2 \pm 8$ years, with a predominance of females $(67 \%)$, being of the male gender a total of $33 \%$. The largest participation of female population in this study could be related to the valorization of autonomy that women tend to 
maintain during the aging process, preserving daily activities and care with themselves ${ }^{18}$. In addition, women have more positive attitudes in relation to health, with lower exposure to risk factors compared to men ${ }^{19.20}$.

Through the MIF, it was possible to identify that the group had a means of $123.1 \pm 4.47$ points, which corresponds to values that indicate the complete functional independence in performing routine tasks without the need for assistance from another individual. When the MIF results were verified by gender, the male sex was $124.4 \pm 3.47$ points and the female $122.45 \pm 4.85$ points. It is possible to realize that both groups have functional independence, since it presented very close values. The gender variable is associated with the occurrence of dependence ${ }^{21}$. However, in this study, the sample of women was higher than that of men, corroborating other studies, where the aging represents a greater prevalence of elderly women with better results of functional independence ${ }^{2.8}$.

When correlated genre and total score of MIF it was found that in the male group there is a weak correlation $(\mathrm{r}=0.09)$. That is, in this group age is not associated with the outcome of MIF. Regarding the female group, it can be seen that there is a strong inverse linear correlation $(\mathrm{r}=$ -0.64). Therefore, the lower the women's age the greater the functional independence in this study.

Considering the domains evaluated of MIF, it was verified that the group domain motor had an average score of $89.73 \pm 13.24$ points. Regarding what corresponds to the subdomains this outcome represented: $46 \%(41.60 \pm 1.10$ points) of the self-care subdomain, $23 \%(20.96 \pm 0.18$ points $)$ mobility, $15 \%$ (13.63 \pm 1.06 points) sphincters control and $15 \%$ (13.53 \pm 1.33 points) locomotion. The subdomain mobility was the one that had the highest score in this category.

It is important to have the knowledge of these data, given that aging brings numerous morphological, biochemical, psychological and functional alterations and can cause dependence in activities ${ }^{7}$. An example of this is the inability to control the sphincters. It was pointed out by a study the association of functional disability related to the health self-perception, and one of its intraindividual factors was urinary incontinence ${ }^{12}$. This situation can negatively affect the individual's social life, especially the elderly, resulting in diseases such as depression, and generate functional incapacity ${ }^{22}$. In addition, Ribeiro et al. ${ }^{23}$ remind that all elderly, before they reach advanced ages, deserve attention with a view to maintaining the independence, even if they do not present any comorbidity, even those living in community with their families and in stable health conditions.

Whereas in the cognitive domain, the group had an average total of $32.83 \pm 3.51$ points, which corresponded to the domains assessed: $58 \%$ to the subdomain of social cognition that had an average of $18.90 \pm 3.30$ points and the communication $42 \%$, $13.93 \pm 0.36$ points. It is perceived in this result a lower score in the category of Social Interaction, Problem Solving and the elderly memory. Lourenço et al. ${ }^{22}$ obtained similar results, in which the elderly presented lower score on attitudes to manage their own cash and make purchases.

Upon correlating the MIF factors and verify what the domains evaluated would be requiring greater care, it was noticed that the factor memory (5.96 points) was the most affected, followed by problems solving ( 6.40 points), both belonging to the cognitive domain. Other factors presented average above 6.50 Points. It is worth mentioning that physical exercise influences on the elderly functional capacity, offering benefits that include nervous system functions, such as the memory, which is directly related to the cognitive functions ${ }^{24}$.

In addition, it was found that the participants aged less than 60 years have greater independence, with total score higher in MIF of $124.00 \pm 2.73$ points, being the cognitive domains of $33.77 \pm 2.22$ points and motor $90.22 \pm 1.98$ points. On the other hand, the participants over the age of 60 years obtained a total score lower on the MIF of $122.71 \pm 5.05$ points, with the cognitive domain with a score of $32.42 \pm 3.88$ points and motor $89.52 \pm 2.29$ points, characterizing them as the most affected group, of lower score. This result corroborates with Rossato et al. ${ }^{25}$, who stated that the greater the individual's age, the lesser the performance will be in cognitive activities.

Finally, it was found out a strong correlation $(r=0.71)$ was found between the total MIF score and the social cognition factor. In addition, a regular correlation was obtained between communication and sphincter control $(r=0.5)$ and between the total score of the MIF with sphincter control $(\mathrm{r}=0.55)$.

When the elderly becomes active, the changes associated with the aging process are reduced, thus ensuring the maintenance and functional capacity and, consequently, better quality of life, ${ }^{26,27}$ and 28 . This is fundamental to propose strategies that aim to annul and/or control the risk factors to health promotion and recovery of impaired functional capacity, taking into account the demographic, socioeconomic, cultural and psychosocial factors ${ }^{27}$.

\section{Conclusion}

The study on the participants' functional independence of the Association of the Elderly, allowed us to observe how is the ability of individuals to perform routine personal activities, their autonomy and difficulties, in addition to checking what aspects need more attention and care.

The assessed group presented complete functional independence in performing routine tasks, without the need for help from other individuals. The research participants aged above 60 years had a lower score in the cognitive and motor domains. A factor to be considered is the development of strategies that work efficiently the elderly's memory and the problems solving, considering that it was the category that showed a lower value in the score of functional independence.

Investments in appropriate professionals as well as the creation of spaces of coexistence should be encouraged to promote strategies and actions aimed at the health promotion and diseases prevention, and the maintenance of 
the independence and autonomy of the elderly of paramount importance for the achievement of better results of an active aging, which promotes the quality of life.

\section{Acknowledgments}

Municipal Department of Health of Teixeira de Freitas-Bahia the collaboration and work in health care and Fundação de Amparo à Pesquisa do Estado da Bahia (FAPESB) for financial support.

\section{References}

1. OPAS - Organização Pan-americana da Saúde. OMS Organização Mundial da Saúde. OPAS/OMS discute como envelhecer de maneira saudável e ativa. 2016. Disponível em https:/www.paho.org/bra/index.php?option=com_content\& view $=$ article \&id=5259:opas-oms-discute-como-envelhecerde-maneira-saudavel-e-ativa \&Itemid $=820$

2. Borges SJ, Rangel RL, Almeida TBLA, Lopes OSL, Oliveira AS, Chaves RN, et al. Avaliação do nível de dependência funcional do idoso com limitação. Saúde Pesq 2019;12(1):169-75. doi: http://dx.doi.org/10.17765/21769206.2019v12n1p169-175

3. Malta DC, Silva Júnior JB. O Plano de Ações Estratégicas para o Enfrentamento das Doenças Crônicas Não Transmissíveis no Brasil e a definição das metas globais para o enfrentamento dessas doenças até 2025: uma revisão. Epidemiol Serv Saúde 2013;22(1):151-64. doi: http://dx.doi.org/10.5123/S167949742013000100016

4. OMS-Organização Mundial de Saúde. CIF: Classificação Internacional de Funcionalidade, Incapacidade e Saúde. São Paulo: EDUSP; 2015.

5. Brasil. Ministério da Saúde. Secretaria de Atenção à Saúde. Departamento de Ações Programáticas e Estratégicas. Área Técnica Saúde do Idoso. Brasília: MS; 2010.

Brasil. Ministério da Saúde. Secretaria de Atenção à Saúde. Departamento de Atenção Básica. Manual do Instrumento de Avaliação da Atenção Primária à Saúde: primary care assessment tool pcatool-Brasil. Brasília: MS; 2010.

6. Cortez ACL, Menezes JMMM, Brandão PP, Silva GCB, Dantas EHM. Correlação entre os testes de avaliação da capacidade funcional de idosos participantes de um projeto de inclusão social na cidade de Teresina-Piauí. J Health Sci 2018;20(4):277-82. doi: http://dx.doi.org/10.17921/24478938.2018v20n4p277-282

7. Nunes DP, Brito TRP, Giacomin KC, Duarte YAO, Lebrão ML. Padrão do desempenho nas atividades de vida diária em idosos no município de São Paulo, nos anos 2000, 2006 e 2010. Rev Bras Epidemiol 2019;21 doi: http://dx.doi. org/10.1590/1980-549720180019.supl.2

8. Veras R. Population aging today: demands, challenges and innovations. Rev Saúde Pública 2009;43(3):548-54. doi: http://dx.doi.org/10.1590/S0034-89102009005000025

9. Monteiro CR, Faro ACM. Functional evaluation of aged with fractures at hospitalization and at home. Rev Esc Enferm USP 2010;44(3):719-24. doi: http://dx.doi.org/10.1590/ S0080-62342010000300024

10. Ribeiro DKMN, Lenardt MH, Lourenço TM, Betiolli SE, Seima MD, Guimarães CA. O emprego da medida de independência funcional em idosos. Rev Gaúcha Enferm 2017;38(4):1-8. doi: http://dx.doi.org/10.1590/19831447.2017 .04 .66496
11. D’Orsi E, Xavier AJ, Ramos LR. Trabalho, suporte social e lazer protegido de queda funcional: estudo epidoso. Rev Saúde Pública 2011;45(4):685-92. doi: http://dx.doi. org/10.1590/S0034-89102011000400007

12. Holtzer R, Wang C, Verghese J. The relationship between attention and gait in aging: facts and fallacies. Motor Control 2012;16(1):64-80. doi: https://doi.org/10.1123/mcj.16.1.64

13. Tomás MT, Galán-Mercant A, Carnero EA, Fernandes B. Functional capacity and levels of physical activity in aging: a 3-year follow-up. Front Med 2018;4:244. doi: https://doi. org/10.3389/fmed.2017.00244

14. Maritz R, Tennant A, Fellinghauer C, Stucki G, Prodinger B. The functional independence measure 18 -item version can be reported as a unidimensional interval-scaled metric: internal construct validity revisited. J Rehabil Med 2019;51(3):193200. doi: https://doi.org/10.2340/16501977-2525

15. Minosso JSM, Amendola F, Alvarenga, MRM, Oliveira MAC. Validação, no Brasil, do Índice de Barthel em idosos atendidos em ambulatórios. Acta Paul Enferm 2010;23(2):218-23. doi: http://dx.doi.org/10.1590/S0103-21002010000200011

16. Schober P, Boer C, Schwarte LA. Correlation coefficients: appropriate use and interpretation. Anesthesia Analgesia 2018;126(5):1763-8. doi: http://dx.doi.org/10.1213/ ANE.0000000000002864

17. Merighi MAB, Oliveira DMD, Jesus MCP, Souto RQ, Thamada AA. Mulheres idosas: desvelando suas vivências e necessidades de cuidado. Rev Esc Enferm USP 2013;47(2):408-14. doi: http://dx.doi.org/10.1590/S008062342013000200019

18. Pilger C, Menon MH, Mathias TAF. Características sociodemográficas e de saúde de idosos: contribuições para os serviços de saúde. Rev Latinoam Enferm 2011;19(5):1230-8. doi: http://dx.doi.org/10.1590/S0104-11692011000500022

19. Lima BM, Araújo FA, Scattolin FAA. Qualidade de vida e independência funcional de idosos frequentadores do clube do idoso do município de Sorocaba. ABCS Health Sci 2016;41(3):168-75. doi:http://dx.doi.org/10.7322/abcshs. v41i3.907

20. Costa TB, Neri AL. Fatores associados às atividades física e social em amostra de idosos brasileiros: dados do Estudo FIBRA. Rev Bras Epidemiol 2019;22:e190022. doi: https:// doi.org/10.1590/1980-549720190022

21. Lourenço TM, Lenardt MH, Kletemberg DF, Seima MD, Carneiro NHK. Independência funcional de idosos longevos na admissão hospitalar. Texto Contexto Enferm 2014;23(3):673-9. doi: http://dx.doi.org/10.1590/010407072014001500013

22. Ribeiro DKMN, Lenardt MH, Michel T, Setoguchi LS, Grden CRB, Oliveira ES. Contributory factors for the functional independence of oldest old. Rev Esc Enferm. USP. 2015;49(1):89-95. doi: https://doi.org/10.1590/S0080623420150000100012

23. Scianni AA, Faria GS, Silva JS, Benfica PA, Faria CDCM. Efeitos do exercício físico no sistema nervoso do indivíduo idoso e suas consequências funcionais, Rev Bras Ciênc Esporte 2018;41(1):81-95. doi: https://doi.org/10.1016/j. rbce.2018.03.026

24. Rossato LC, Contreira AR, Corazza ST. Análise do tempo de reação e do estado cognitivo em idosas praticantes de atividades físicas. Fisioter Pesq 2011;18(1):54-9. doi: http:// dx.doi.org/10.1590/S1809-29502011000100010

25. Pisu M, Demark-Wahnefried W, Kezink M, Oster RA, Lin CP, 
Manne S, et al. A dance intervention for cancer survivors and their partners (RHYTHM). J Cancer Surviv 2017;11(3):350359. doi: http://dx.doi.org/10.1007/s11764-016-0593-9

26. Silva AM, Castro LFA, Botelho, ACF, Santos DR, Frutuoso JRC, Marques AP, et al. Equilíbrio, autonomia e independência funcional de idosos ativos e sedentários: estudo preliminar. Rev Kairos 2015;18(18):129-42.

27. Borges GF, Benedetti TRBT, Farias SF. Atividade física habitual e capacidade funcional percebida. Pensar Prática 2011;14(1):1-11. doi: https://doi.org/10.5216/rpp. v14i1.12314

28. Freire Júnior RC, Fernandes TG, Borges GF, Guerra RO, Abreu DCC. Factors associated with low levels of physical activity among elderly residents in a small urban area in the interior of the Brazilian Amazon. Arch Gerontol Geriatr 2018;75:37-43. doi: https://doi.org/10.1016/j. archger.2017.11.007 